Final article:

Lindgreen, A. and Swaen, V. (2004), "Corporate citizenship: let not relationship marketing escape the management toolbox", Corporate Reputation Review, Vol. 7, No. 4, pp. 346-363. (ISSN 1363-3589)

For full article, please contact LindgreenA@cardiff.ac.uk

\title{
Corporate Citizenship:
}

\section{Let Not Relationship Marketing Escape the Management Toolbox}

\author{
Dr. Adam Lindgreen ${ }^{1,2}$ \\ Eindhoven University of Technology, the Netherlands
}

\author{
Ms. Valérie Swaen ${ }^{3}$ \\ Catholic University of Louvain, Belgium \\ IESEG School of Management, France
}

\footnotetext{
1 Address for all correspondence: Adam Lindgreen, Department of Organisation Science and Marketing, Eindhoven Centre of Innovation Studies, Faculty of Technology Management, TEMA 007, Eindhoven University of Technology, Den Dolech 2, P.O. Box 513, 5600 MB Eindhoven, the Netherlands. Telephone: + $31-(0) 40247$ 3700. Fax: + 31 - (0) 40246 5949. E-mail: a.lindgreen@tm.tue.nl.

${ }^{2}$ Thanks many times to the reviewers for their constructive feedback on previous drafts of this article.

${ }^{3}$ Valérie Swaen, Department of Marketing, Institut d'Administration et Gestion, Catholic University of Louvain, Place des Doyens 1, 1348 Louvain-la-Neuve, Belgium. Telephone: + 32 - (0) 10479156. Fax: + 32 - (0) 1047 8324. E-mail: swaen@mark.ucl.ac.be. The author is a research fellow with the Belgian National Fund for Scientific Research and the Bernheim Foundation, as well as a visiting research fellow with the IESEG School of Management, France.
} 


\section{Corporate Citizenship:}

\section{Let Not Relationship Marketing Escape the Management Tool Box}

\section{ABSTRACT}

Over the past decades, there has been a continual proliferation in marketing concepts and 'paradigms' that supposedly offer solutions to the challenges that companies are facing. Relationship marketing is one such concept that has moved to the forefront of research and practice; it promises companies a management tool to build economically profitable relationships, networks, and interactions with different, but equally important stakeholder markets. Corporate citizenship is another concept that has become increasingly popular with researchers and practitioners alike. The argument is that companies should seek to fulfill their legal, ethical, economic, and discretionary obligations to shareholders, employees, customers, and the community at large. The objective of our paper is to demonstrate that companies, which seek to implement corporate citizenship, consciously, but more frequently unconsciously, employ relationship marketing tools. By way of real-life examples we show how the use of such tools has facilitated the implementation of corporate citizenship. The paper is organized as follows. We first review the literatures on relationship marketing and corporate citizenship. Then we discuss different corporate citizenship initiatives relating this discussion to relationship marketing. Lastly, we outline future research that can examine further the proposed relationship between corporate citizenship and relationship marketing. 


\section{INTRODUCTION}

'Relationship marketing' is a concept that has moved rapidly to the forefront of research and practice with many referring to it as a new marketing paradigm (Fournier, Dobscha, and Mick 1998; Grönroos 1994; Gummesson 1999). Relationship marketing promises companies a management tool to build economically profitable relationships, networks, and interactions with different, but equally important stakeholder markets (Christopher, Payne, and Ballantyne 1991; Gummesson 1999; Morgan and Hunt 1994). The toolbox consists of database marketing, E-marketing, interaction marketing, and network marketing (e.g., Coviello, Brodie, Danaher, and Johnston 2002).

The concept of 'corporate citizenship' (e.g., Laufer 1996; Maignan and Ferrell 1998; Pinkston and Carroll 1994) is one in a series of related business philosophies such as 'corporate social responsibility' (Bowen 1953; Carroll 1979; Mason 1960), 'corporate social responsiveness' (Ackerman and Bauer 1976; Frederick 1998; Strand 1983), and 'corporate social performance' (Stanwick and Stanwick 1998; Swanson, 1995; Wood 1991). The idea behind these concepts is that it is no longer enough for companies to be concerned only with seeking a profit - they should also 'give something back to the society at large', for example their employees or the local society in which they operate. Corporate citizenship has become increasingly popular with researchers (Brown and Dacin 1997; Handelman and Arnold 1999; Osterhus 1997; Sen and Bhattacharya, 2001), as well as practitioners including the Suez Group (Fortin 2001), l'Oréal (Ladurée 2001), IBM (Launay 2001), and Danone (Giraud 2001). Some observers suggest that corporate citizenship activities should not be regarded as 
'corporate do good', but rather as the entry ticket for doing business in the twenty-first century (Altman 1998) thereby illustrating the growing belief that responsible management is inextricably linked to corporate survival.

We propose that companies seeking to implement good corporate citizenship would benefit from employing relationship marketing tools. For example, Ferrell, Fraedrich, and Ferrell (2002) describe Herman Miller, Inc., which is a multinational provider of office, residential, and health care furniture and services. The company has verbalized and written Blueprint for Corporate Community, a document that demonstrates a strategic focus on corporate citizenship and that applies to all the company's operations, products, markets, and business relationships. The company believes in 'making a meaningful contribution to our customers', 'cultivating community, participating, and people development', and 'creating economic value for shareholders and employee-owners' (Ferrell, Fraedrich, and Ferrell 2002: p. 75). This real-life example of Herman Miller, Inc. suggests that companies, which are good corporate citizens, seek to fulfill their legal, ethical, economic, and discretionary obligations to a wide range of markets including shareholders, customers, employees, and the community at large (Klusmann 2000). In other words, such companies direct their marketing activities to numerous stakeholders, which is exactly what relationship marketing suggests that companies must do.

The article now proceeds to examine in more depth relationship marketing and corporate citizenship; from this examination the reader will appreciate how the implementation of corporate citizenship can be supported by relationship marketing tools. 


\section{RELATIONSHIP MARKETING}

Parvatiyar and Sheth (2000: p. 3) contend that '[...] the conceptual foundations of relationship are not fully developed as yet', but although there is no consensus at this point of time on what relationship marketing constitutes most writers agree, however, that its focus is on customer retention rather than customer attraction, which is the topic of transaction marketing or, as it is also known, traditional marketing or 4Ps marketing with the 4Ps referring to product, price, place, and promotion (e.g., Berry 1983; Grönroos 1994; Jackson 1985; Morgan and Hunt 1994). To understand relationship marketing it is useful to employ a vertical approach whereby the various 'schools of thought' within relationship marketing can be analyzed. These schools are drawn together by a recognition of, and commitment to, relationship marketing through joint research, publications, and practice (Palmer 2001; Sheth and Parvatiyar 2000). We therefore proceed to examine, firstly, the foundations of these schools and, secondly, practical approaches to implementing relationship marketing, as this could potentially provide interesting insights into how companies can realize their vision of being a good corporate citizenship.

\section{Schools Of Thought Within Relationship Marketing}

Three schools of thought have been identified in the literature (Lindgreen 2000; Palmer 2001; Sheth and Parvatiyar 2000): the Industrial and Marketing Purchasing (IMP) group, the Nordic perspective, and the UK (Anglo-Australian) school. 
(1) The IMP group: The relationships, which exist between buyers and sellers, are built from interaction processes, and considerations have been given to these processes on key technical, social (e.g., trust, commitment, and influence/power), and economic issues. Another observation is that business relationships are connected through a wider economic organization ('network form'). Lastly, relationships are a combination of individual adaptations (i.e. personalized market relationships that are over and above the 4Ps) and scale-effective production (i.e. mass market relationships through the 4Ps), as well as a confrontation through which different dimensions of resources are identified and utilized by the two parties (Håkansson and Snehota 2000).

(2) The Nordic perspective: A successful relationship marketing strategy requires that the interaction process, dialogue process, and value process be accounted for. The first process takes place between a supplier of goods or services and a single customer or a group of buyers, users, and decision makers. It is also possible that more parties in a network are involved (Grönroos 1996; Gummesson 1996). The dialogue process is necessary for supporting the successful establishment, maintenance, and enhancement of the interaction process (Schultz, Tannenbaum, and Lauterborn 1992). The third process is required for showing how the customer 'perceives the creation and transfer of value over time' (Grönroos 2000: p. 102). Value is created, and partly transferred, in the interaction process, and supported during the interaction process.

(3) The UK (Anglo-Australian) school: Relationship marketing is essentially an alignment of marketing, quality, and customer service, and businesses should formulate their marketing activities to, and build relationships with, six equally important markets, namely the customer, supplier alliance, internal, recruitment, 
influence (e.g. government bodies), and referral markets (e.g. customers' word-ofmouth). When marketers consider each of these markets in order to provide the best value proposition in terms of the product and customer service the result is that relationship marketing is 'emerging as the new focal point integrating customer service and quality with a market orientation' (Christopher, Payne, and Ballantyne 1991: p. 4).

Table 1 compares and contrasts the three schools on key variables in marketing orientation and activities. Transaction marketing has been included in the table, too. Although the schools differ from each other they broadly see relationship marketing as a means "to establish, maintain, and enhance relationships with customers and other partners, at a profit, so that the objectives of the parties involved are met. This is achieved by a mutual exchange and fulfillment of promises. Such relationships are usually but not necessarily always long term" (Grönroos 1994: p. 355).

[Insert Table 1 around here]

\section{Practical Approaches To Implementing Relationship Marketing}

Together with her colleagues, Coviello has been examining contemporary marketing practice using a classification scheme, which builds upon content analysis of how European and North American schools have defined marketing in the literature (e.g., Brodie, Brookes, and Coviello 2000; Brodie, Coviello, Brookes, and Little 1997; Coviello, Brodie, Danaher, and Johnston 2002; Coviello, Brodie, and Munro 1997; Lindgreen, Davis, Brodie, and Buchanan-Oliver 2000). The scheme is based upon two 
themes, namely relational exchange (with five dimensions; Table 2) and management activities and processes (with four dimensions; Table 3). Transaction marketing and relationship marketing are identified as two general marketing perspectives, and these perspectives encompass five distinct types of marketing, i.e. transaction marketing, database marketing, E-marketing, interaction marketing, and network marketing. The scheme places no distinct boundaries between the five types of marketing, which also are not necessarily independent and mutually exclusive.

\section{[Insert Tables 2 and 3 around here]}

Relational-oriented organizations focus less on conventional marketing tools such as the 4Ps and more on internal marketing assets (employee and information technologybased interactivity) and external marketing assets (developing relationships and networks with other organizations). This has importance for the communication pattern that tends to be from the organization to the mass market in transaction marketing, but between the organization and individual customers in relationship marketing where the type of contact is more personalized and interactive.

\section{CORPORATE CITIZENSHIP}

The earliest conceptualizations of corporate citizenship were developed in the 1950s in the research area of business responsibility. For example, Bowen (1953) argued that business people have the obligation to pursue desirable policies in terms of societal objectives and values. Carroll (1979: p. 500) specified that obligations of companies must 'encompass the economic, legal, ethical and discretionary 
expectations that society has of organizations at a given point in time'. While corporate citizenship is a term commonly used (Andriof and McIntosh 2001), no single definition has been widely accepted and multiple conceptualizations coexist. Although many different business organizations and researchers have attempted to provide their own definitions of corporate citizenship (Table 4), corporate citizenship generally refers to business decision-making linked to ethical values, compliance with legal requirements, and respect for people, communities, and the environment.

\section{[Insert Table 4 around here]}

Building upon the work of Carroll (1979), Maignan (1997) suggested an operational definition and developed a measurement tool that has later been validated in the US (Maignan, Ferrell, and Hult 1999) and France (Maignan and Ferrell 2001). The conceptualization is comprised of four dimensions:

(1) Economic citizenship, which requires companies to be productive and profitable and to meet the needs of consumers;

(2) Legal citizenship meaning that companies work within the legal framework;

(3) Ethical citizenship according to which companies must follow socially established moral standards; and

(4) Discretionary citizenship where companies assume voluntary activities aimed at helping other people and contributing to the well being of the communities in which they operate.

Martin (2002: p. 69) recently argued that consumers, investors, and business leaders alike increasingly now pressure companies to 'remember their obligations to the 
employees, communities, and environment'. Companies do not operate in a universe composed solely of shareholders, but exist within larger networks with financial, political, and social members all of whom put pressure on the companies (Martin 2002). A good corporate citizen has the duty to address the concerns, and to satisfy the demands, of its main stakeholders, i.e. those actors who, directly or indirectly, can affect, or be affected by, corporate activities (e.g., Donaldson and Preston 1995; Jones 1995; Waddock 2001). Stakeholders include shareholders, customers, suppliers, employees, the media, (governmental) regulators, and pressure groups, amongst others.

\section{Driving Forces Of Corporate Citizenship}

There are situations in which businesses have no internal drive to engage in corporate citizenship, but nevertheless are compelled to do so by their stakeholders. However, there are also cases where businesses are self-driven to invest in corporate citizenship, and to implement desirable actions, independently of any stakeholder pressure. Driving forces of corporate citizenship can be grouped in three separate but interlinked categories: (1) stakeholders' pressures, (2) top management orientation, and (3) corporate culture.

(1) Stakeholders' pressure: Shareholders, employees, and other stakeholders supply different kinds of resources necessary for the company's functioning (human, financial, technical, and technological resources), and the availability of those resources determines the company's ability to survive. Consequently, stakeholders could exercise pressure on a company they consider is not acting in a 'desirable' way. 
In recent years - with access to instant and free information from a variety of sources and to a multitude of service/product providers - various stakeholders have come to expect more of business (McIntosh, Leipziger, Jones, and Coleman 1998). They are looking to the private sector to help with myriad complex and pressing social and economic issues, and companies are put under increasing pressure to exhibit good corporate citizenship (Pinkston and Carroll 1994). For instance, in a study by Environics, the Conference Board, and the Prince of Wales Business Leadership Forum in 1999, 17 per cent of 25,000 survey respondents reported that they had avoided the products of companies they perceived as not being socially responsible supporting the idea that consumers want to act in conformity to certain values. Another case is the pressure from supply chain partners: Companies that decide to become better corporate citizens seek to buy materials and resources from suppliers who are considered as environmentally correct and ethically sound, and many large companies now require their suppliers to provide details on their social responsibility policies. The pressure for better social and environmental performance can then 'move along' the value chain (Warhurst 2001). It is a formidable force, as large companies can effectively exclude suppliers from the marketplace if they are not socially responsible. The use of child labor and the protection of social diversity are important issues within this context, too.

(2) Top management orientations: Managers constitute a particular group of stakeholders with respect to corporate citizenship matters. They are inside the company and have consequently an easy access to, or are themselves, the people in charge of the decision making related to corporate citizenship activities. They may assess the relevance and importance of the stakeholders' issues, select the ones that the 
company will take into account, and participate in the implementation of the corporate citizenship decisions. Managers are then the group of stakeholders likely to have the biggest influence on the degree of a company's involvement in corporate citizenship. The values and ideals of managers seem to impact on the extent to which a company adopts a corporate citizenship strategy. Thomas and Simerly (1995) studied the relationships between the background of top managers and corporate citizenship and suggested that managers with different backgrounds hold different values and thus do not attribute the same importance to corporate citizenship. In the same vein, Miles (1987) advances that top management beliefs about the role of corporations in society influence the companies' responses to social pressures. This could be part of the explanation why companies in the same industry exhibit different social responsibilities to similar pressures (Bhambri and Sonnenfeld 1988; Gray 1983). Drumwright (1994) highlighted the role of 'policy entrepreneurs' (people who play a key role in bringing issues to the forefront) in taking environmental issues in as a core criterion in organizational buying decisions. These people are willing to invest their resources (e.g., time and energy) in hope of a future return (e.g., policies that they approve or satisfaction from participation). In a specific company, the presence of policy entrepreneurs who are personally interested in putting social and environmental issues on the corporate agenda may thus influence the degree of corporate citizenship of that company.

(3) Corporate culture: The corporate culture may guide managers in how they address different issues that their companies are facing. Some researchers have seen links between the corporate culture, the orientation to different stakeholders, and the degree of involvement in corporate citizenship activities. For example, the more humanistic 
the organization's culture is, the more likely the firm is to practice corporate citizenship (Maignan, Ferrell, and Hult 1999): The importance attributed to collaboration and harmony among workers, as well as among the company and its different stakeholders is high. These authors showed that a humanistic orientation permits to improve the relationships between the company and its stakeholders by meeting their expectations in economic, legal, ethical, and discretionary areas. Also, market-oriented corporate cultures are more inclined to invest in corporate citizenship than cultures that are less market oriented (Maignan, Ferrell, and Hult 1999; ZarkadaFraser 1999). Market-oriented cultures are characterized by a certain sensitivity and responsiveness to any stakeholder or issue that may affect the company's long-term performance (Narver and Slater 1990), and Maignan, Ferrell, and Hult (1999) argue that market-oriented organizations integrate their social responsibilities into their activities more than what less market-oriented do.

\section{Outcomes Of Corporate Citizenship}

Several studies have considered the financial effects of corporate citizenship on organizational performance (e.g., Abbott and Monsen 1979; Arlow and Gannon 1982; Aupperle, Carroll, and Hatfield 1985; Stanwick and Stanwick 1998; Ullmann 1985), but a relationship between corporate citizenship and economic performance has not yet been established univocally (Aupperle, Carroll, and Hatfield 1985; Griffin and Mahon 1997). Most researchers have highlighted a positive relationship because of the potential for increasing sales and reducing costs (e.g., Maignan and Ferrell 2001; Waddock and Graves 1997; Wokutch and Spencer 1987), whereas others have observed a negative relationship that is contributed to the costs of investing in 
corporate citizenship (e.g., Davidson and Worrell 1988; Vance 1975). Yet a third group of researchers have found evidence that would suggest no relationship at all (e.g., Aupperle, Carroll, and Hatfield 1985; Davidson and Worrell 1990; McGuire, Sundgren, and Schneeweis 1988).

The impact of corporate citizenship activities on stakeholders' attitudes and behaviors toward the corporate citizen company has been investigated although not well developed. It is contended that by reaching out to the stakeholders the company can increase its revenues and profits so that it will survive in the long run. Corporate citizenship seems to influence the attractiveness of the company as a potential employer (Turban and Greening 1997) and to impact on the degree of current employees' commitment toward the company (Maignan and Ferrell 2001; Maignan, Ferrell, and Hult 1999). Furthermore, in a survey conducted by the Conference Board, executives reported that volunteer programs improved employee productivity and morale, fostered team work, and skill building. Another recent survey indicated that 84 percent of managers regard the achievement of a responsible image in the community as important for employee morale (Business Ethics 1997). Corporate citizenship initiatives may help establish a bond between the organization and its employees (Leonard 1997). With respect to consumers, the awareness of corporate citizenship practices appears to have a positive influence on (1) consumers' evaluation of product attributes (Brown and Dacin 1997), (2) attitudes toward the firm (Brown and Dacin 1997; Creyer and Ross 1997; Murray and Vogel 1997), and (3) corporate reputation (Fombrun and Shanley 1990). Maignan, Ferrell, and Hult (1999) have also highlighted the positive impact of corporate citizenship on customer loyalty. 


\section{RELATIONSHIP MARKETING: SERVICING CORPORATE CITIZENSHIP}

We would not expect corporate citizenship to use elements from transaction marketing, which is about short-term market exchanges and mostly focused on the product and its technical aspects and quality. Rather, corporate citizenship is implemented through relationships, networks, and interactions with different stakeholders, the area of relationship marketing (Gummesson 1999; Martin 2002). Consider for example the organization that is responding to customers' increased worry for the environment and, as a result, consults the following departments (Drumwright 1994, 1996): operations management (e.g., how to produce the goods in a more environmentally friendly manner); packaging (e.g., how to package the goods using less materials); and marketing (e.g., how to communicate that the goods are now produced in a more environmentally friendly manner). In other words, social and environmental problems require collaboration across an organization's different departments just as a cross-departmental culture is needed in the company practicing relationship marketing. Using Tables 2 and 3, we will now continue to examine how relational marketing tools are useful in implementing corporate citizenship.

\section{Database marketing}

With most of its activities embedded in a network of stakeholder relationships, an organization needs to make sure that the stakeholders understand the network brings real meaning. Because network building requires that stakeholders and their interests be identified (Gao and Zhang 2001) database marketing is often the first tool that companies utilize when pursuing a corporate citizenship initiative. Indeed, companies 
need to collect information about stakeholders and their expectations to a variety of social, ethical, and environmental issues. Dyadic processes between the company and its (internal and external) stakeholders form a necessary basis for developing constructive relationships in a market that changes rapidly; managing stakeholders as if they were discrete and unconnected is not a viable strategy. Instead the company must develop systems and approaches that enable it to prioritize stakeholders, to align itself with these stakeholders, to integrate its messages to and from the stakeholders, and to build bridges between itself and the stakeholders in order to pursue common goals, rather than to attempt to set up a buffer between the two sides (Andriof 2001). Consider for example British Telecom, which is one of the world's largest providers of telecommunications. It wanted to identify the factors that its stakeholders considered to be the most significant social impacts and effects of British Telecom. In a social auditing process, the independent research organization MORI carried out a stakeholder consultation comprised of a series of 12 focus group discussions and 18 one-to-one interviews with representatives of British Telecom's key stakeholders (i.e., employees, customers, institutional investors, private shareholders, opinion leaders, the community, and experts in the field of social reporting).

The following is another example of how companies learn to listen from the stakeholders. In 1998, the Co-Operative bank in the UK produced a partnership report committing the bank to deliver benefits to its partners in a socially responsible and ecologically sustainable manner. A partnership ballot was used to gather data and assess stakeholders' opinions on specific issues (via questionnaire surveys, focus groups, and interviews). The bank's approach was first to establish a partnership development team the responsibility of which was to undertake a detailed assessment 
of the bank's performance in relation to each stakeholder group. Following this assessment the team sought to determine each partner's priorities, his relationship with the bank, and the degree to which the bank delivers value in the required manner.

\section{E-marketing}

Citizenship is often an element of a firm's published identity: core values, codes of conduct, policy statements, and publications that typically refer to the firm's commitment to its stakeholders. Good corporate citizens try to demonstrate that they are aware of the environmental, social, and ethical issues that their stakeholders face, and that they are ready to enter into a dialogue with them to find solutions. For example, businesses with a high ecological impact put information about their environmental management programs on the Web. This, too, is the case for companies that have been sharply criticized for wrongdoing: they may use the Web in an effort to rehabilitate their public images. A case in point is Royal Dutch Shell that emphasizes its citizenship commitments: the environment, human rights, and community involvement.

Also with E-marketing, cost-efficient monitoring and verification tools become an indispensable part of stakeholder assessment and feedback. Himaya - a for-profit eorganization selling products labeled 'made in Europe' and 'not produced by children' is using the Internet (www.himaya.org) for selling its products and for communicating with its customers, notably through discussion forums. The Internet thus offers the opportunity for creating a direct dialogue between the company and its stakeholders around social and ethical issues, as well as direct interactions between the 
stakeholders themselves. The Internet has enabled such companies to reach a wide range of customers, and to communicate with these customers in a new way. The relationships are different from transactional ones because they are interactive and no longer impersonal arms-length relationships.

Another example is IBM France that uses Intranets to provide its employees with information on IBM principles so as to secure that employees become loyal to these principles. More particularly, with access to the Intranet pages, social partners have the opportunity to communicate with each other during a negotiation process, and those partners who do not sign the agreement can still send their comments to IBM France.

Lastly, numerous companies employ the Internet to give information about their corporate citizenship initiatives and to collect information about the stakeholders' expectations to social, ethical, and environmental issues. For example, Auchan puts much information on the Web, notably about genetically modified organisms. Visiting the homepage of Wainwright Bank and Trust Company, a US \$300 million Boston commercial bank, one will find that it is infused with a sense of mission speaking openly of the bank's commitment to its stakeholders (Glazebrook 2001). Wainwright is the national leader in financing shelters for the homeless people, and community development loans constitute one fifth of its portfolio. Indeed, the bank subscribes to the demanding Coalition for Environmentally Responsible Economies principles. 


\section{Interaction marketing}

There are many forms of social partnerships that involve institutions from different sectors of the community (business, government, civil society) coming together in addressing common purposes that involve the realization of both social and commercial ends. The Copenhagen Centre has defined these new social partnerships as 'People and organizations from some combination of public, business and civil constituencies who engage in voluntary, mutually beneficial, innovative relationships to address common societal aims through combining their resources and competences' (Zadek 2001).

Taking stakeholders into consideration does not necessarily mean that their needs and interests are always accommodated for, rather that they are appreciated and that mutual accommodation can be achieved with multiple sets of needs and interests understood and considered. Achieving this level of stakeholder interaction means that leaders have the necessary capacities for understanding the perspectives of others. Such wisdom, integrity, and honesty are needed for successful corporate citizenship.

A case in point is that when BP's operations in Columbia faced accusations of human rights abuses and environmental damages (The Guardian 1998) it changed from being technology driven to be society driven. BP has now built partnerships with local NGOs that have enabled the company to manage social risks, to become part of the society, and to become a sustainable company with the prospect of long-term prosperity (Andriof 2000). The source of benefits for both partners (BP and the 
NGOs) has been the potential of exchanging knowledge necessary in achieving the strategic objective of a changing business policy.

Another case in point is Danone that had to decide on which factories to close in a restructuring process. Danone established a voluntary process of information and dialogue between company leaders, employee representatives, and labor unions. The goals were to associate the employees' representatives in understanding different economic scenarios and to allow for a dialogue on the social plan measures. The company demonstrated that it valued the thinking together about organizational changes in the company, and it also committed itself to studying alternative solutions proposed by social partners (Giraud 2001).

\section{Network marketing}

Ecological crisis, organized crime, and international justice are all examples of issues that cannot be resolved by a global administration that provides an institutional framework, as we know it from the national context. Rather, what is needed are networks of co-operation between responsible leaders in different branches of the society. For example, the British retail chain Sainsbury's works with other companies, NGOs, labor organizations, and the government under an Ethical Trading Initiative: the issue is labor standards in global supply chains where Sainsbury's recognizes the potential gains from different competences, as well as shared learning and distinct reputations and credibility. Another example is the French utilities giant, Suez Lyonnaise des Eaux, which works with Brazilian community groups in designing a mechanism of delivering water to low-income areas in a commercially viable and 
politically sensitive manner recognizing its lack of competences in realizing this challenge. In both examples the actors are consciously seeking opportunities that enable relationships allowing them to get the maximum effectiveness and value of their own (perceived) core competences and capacities.

On 26 July 2000, executives from 50 multinational corporations - including Bayer, Nike, DuPont, Royal Dutch Shell, and Unilever - met with the secretary-general of the United Nations to commit their companies to a set of principles in the areas of environment, labor, and human rights (e.g., eliminating child labor, allowing free trade unions, refraining from polluting the environment). The leaders of a dozen labors unions and civil society organizations were also present. The careful engagement of businesses in partnerships with the agencies of the UN system to improve environmental, human rights, and labor standards has great potential. There is a possibility of sharing best practices and bringing increased expertise, resources, and delivery systems to the table.

Companies, even when they are competitors, can choose to work together on social issues. An example of this kind of network is the alliance between the French retailers Carrefour, Auchan, Casino, Cora, and Système U and their principal suppliers. In 1998, they decided to work together on a program that consists of auditing suppliers from developing countries on the basis of a common reference point (SA 8000) and of confronting the obtained results and information (Bedier 2001). The underlying objective is to make suppliers from developing countries understand the commercial interest of becoming socially responsible. In this alliance, retailers seek mutual benefit and resource exchange. One advantage of the network is that through the relationships 
the suppliers and retailers have gained an understanding and appreciation of the problems that their business partners deal with.

Another well-known network is 'Responsible Care' that translates the commitment of the chemical industry to demonstrate a continuous improvement of its performances with respect to health, security, and environment and to answer to public expectations. The main principles of Responsible Care are the following: communication at all levels (local, national, international, global), ability to listen (and not only to give its views), identification of the best practices in each country (about health and safety, protection of the environment, responsible management of products), and share of experiences and evaluation by third parties. Because of Responsible Care the chemical industry can show an improvement in security and a reduction in air pollution and resource waste, as well as an improvement in communication with local communities, employees, organizations, and governments.

\section{CONCLUSIONS}

Our paper offers insights into how the implementation of good corporate citizenship is facilitated by employing relationship marketing tools. Meaningful stakeholder engagement should be a genuine process of sharing views between the stakeholders and the management of an organization for the purpose of improving the social, ethical, and environmental performance of the organization and for improving its accountability. 
The paper demonstrates how a good corporate citizenship must reach out to many different stakeholders. It has to listen and respond to the stakeholders that form part of its relationships, networks, and interactions, and it has particularly to avoid making assumptions. It is becoming dangerous - even for experienced managers - to make any assumption about what is best for stakeholders: in the genetically modified organisms debate, Monsanto recognized that it was a mistake not taking into account the perceptions of the different publics in Europe. It is essential to understand the realities of the business through the eyes of stakeholders. This requires an ability to comprehend how they perceive the business and to be open to improvement and change.

Another interesting example is Nike that was accused of using children to produce its products in Asia. Nike learned the hard way that even when its activities are perfectly legal, it could still lose revenue and suffer damage to its reputation if it ignores its wider stakeholders. The relationships between Nike and its suppliers obviously were far from interpersonal and close as they should have been, and they also were not based upon commitment, trust, and co-operation. On the basis of that image crisis, Nike's management started to ask some serious questions: how to prevent this happening in future? What to do to protect company's reputation? How to better understand those social and ethical issues? Nike began to use the tool box of relationship marketing and to invest in social and environmental issues those stakeholders care about. Demonstrating concern creates a general atmosphere of trust and a better understanding of corporate aims so that when the next crisis comes, there will be greater goodwill enabling the company to survive. 
Acknowledging that our paper builds upon anecdotal evidence, we suggest that future research examines in more depth the relationship between corporate citizenship and relationship marketing. We propose to follow the protocol that the contemporary marketing practice group has established according to which convenience samples of managers participating in executive MBA programs are being used. Although this approach is not random in its nature, it is an approach that is practical and controllable (Coviello, Brodie, Danaher, and Johnston 2002). Previous studies on contemporary marketing practice have used a self-administered structured questionnaire developed to collect quantitative data pertaining to the various aspects of marketing practice, as well as respondent and organizational demographics.

In order to measure the degree of corporate citizenship we propose to use the measurement tool of Maignan (1997) who considers corporate citizenship as a multidimensional construct based on information provided by managers; the scale adopts a multidimensional perspective of corporate citizenship and has demonstrated good psychometric properties in different countries including the US and France. With regard to relationship marketing we propose to use a questionnaire that is organized around topics such as the company's customers, marketing practices, use of technology, as well as value creation and delivery in the company and the respondent's view on marketing (Coviello, Brodie, Danaher, and Johnston 2002).

Interesting findings should result from the outlined study. For example, the company size and the industry type may influence the propensity of organizations to engage in corporate citizenship or relationship marketing: On the basis of an analysis of companies in the Fortune index, Stanwick and Stanwick (1998) found a positive 
correlation between the size of a company (as measured by its annual sales) and the level of social performance. In the same vein, some industries may be more likely than others to engage in corporate citizenship activities, perhaps because of the presence of fewer pressures, or the features of the sector (e.g., non-polluting sector). The research would help to know appropriate marketing strategies and practices, which can help creating and maintaining positive stakeholders' perceptions of, and reactions to, the corporate citizens. This kind of research is of great relevance to managers at a time where sustainable development has been put at the political and managerial agenda. It also means that corporate citizens should look toward relationship marketing, as its relevance is clear.

\section{REFERENCES}

Abbott, W. F. and Monsen, J. R. (1979) 'On the measurement of corporate social responsibility', Academy of Management Journal, 22 (3): 501-515.

Ackerman, R. W. and Bauer, R. A. (1976) Corporate Social Responsiveness. Reston Publishing, Reston.

Altman, B. W. (1998) 'Transformed corporate community relations: a management tool for achieving corporate citizenship', Business and Society Review, 102/103: $43-51$.

Andriof, J. (2000) Managing Social Risk through Stakeholder Partnership Building. $\mathrm{PhD}$ thesis. Warwick Business School, Coventry, UK.

Andriof, J. (2001) 'Patterns of stakeholder partnership building', in J. Andriof and M. McIntosh (Eds.), Perspectives on Corporate Citizenship, Greenleaf Publishing, UK: $215-238$. 
Andriof, J. and Marsden, C. (2000) 'Corporate citizenship: what is it and how to assess it?' in M. McIntosh and A. Warhurst (Eds.), Third Annual Warwick Corporate Citizenship Unit Conference: 1-12, July 10, University of Warwick, UK.

Andriof, J. and McIntosh, M. (2001) Perspectives on Corporate Citizenship. Greenleaf Publishing, UK.

Arlow, P. and Gannon, M. J. (1982) 'Social responsiveness, corporate structure, and economic performance', Academy of Management Review, 7 (2): 235-241.

Aupperle, K. E., Carroll, A. B., and Hatfield, J. D. (1985) 'An empirical examination of the relationship between corporate social responsibility and profitability', Academy of Management Journal, 28 (2): 446-463.

Barone, M. J., Miyazaki, A. D., and Taylor, K. A. (2000) 'The influence of causerelated marketing on consumer choice: does one good turn deserve another?' Journal of the Academy of Marketing Science, 28 (2): 248-262.

Bedier, J. (2001) 'La démarche de la grande distribution française', in P. d'Humières and A. Chauveau (Eds.), Les pionniers de l'entreprise responsable: 47-53, Editions d'Organisation, Paris.

Bendapudi N., Singh, S. N., and Bendapudi, V. (1996) 'Enhancing helping behavior: an integrative framework for promotion planning', Journal of Marketing, 60 (3): $33-49$.

Berry, L. L. (1983) 'Relationship marketing', in L. L. Berry, G. L. Shostack, and G. D. Upah (Eds.), Emerging Perspectives on Services Marketing: 25-28, American Marketing Association, Chicago-Illinois. 
Bhambri, A. and Sonnenfeld, J. (1988), 'Organization structure and corporate social performance: a field study in two contrasting industries', Academy of Management Journal, 1 (3): 642-662.

Bowen, H. R. (1953) Social Responsibilities of the Businessman, New York, HarperRow.

Brodie, R. J., Brookes, R. W., and Coviello, N. E. (2000) 'Relationship marketing in consumer markets', in K. Blois (Ed.), The Oxford Textbook on Marketing: 517-533, Oxford University Press, Oxford.

Brodie, R. J., Coviello, N. E., Brookes, R. W., and Little, V. (1997) 'Towards a paradigm shift in marketing: an examination of current marketing practices', Journal of Marketing Management, 13 (5): 383-406.

Brown, T. J. and Dacin, P. A. (1997) 'The company and the product: corporate associations and consumer product responses', Journal of Marketing, 61 (1): 68-84.

Business Ethics (1997) 'Does it pay to be ethical?', March/April: 15.

Carroll, A. B. (1979) 'A three-dimensional conceptual model of corporate performance', Academy of Management Review, 4 (4): 497-505.

Carroll, A. B. (1998) 'The four faces of corporate citizenship', Business and Society Review, 100/101: 1-7.

Christopher, M., Payne, A., and Ballantyne, D. (1991) Relationship Marketing: Bringing Quality, Customer Service, and Marketing Together, ButterworthHeinemann, Oxford.

Coviello, N. E., Brodie, R. J., Danaher, P. J., and Johnston, W. J. (2002) 'How firms relate to their markets: an empirical examination of contemporary marketing practices', Journal of Marketing, 66 (3): 33-46. 
Coviello, N. E., Brodie, R. J., and Munro, H. J. (1997) 'Understanding contemporary marketing: development of a classification scheme', Journal of Marketing Management, 13 (6): 501-22.

Coviello, N., Milley, R., and Marcolin, B. (2001) 'Understanding IT-enabled interactivity in contemporary marketing', Journal of Interactive Marketing, 15 (4): $18-33$

Creyer, E. H. and Ross, W. T. (1997) 'The influence of firm behavior on purchase intention: do consumers really care about business ethics?' Journal of Consumer Marketing, 14 (6): 421-432.

Davidson, W. N. and Worrell, D. L. (1988) 'The impact of announcements of corporate illegalities on shareholder returns', Academy of Management Journal, 31 (1): 195-200.

Davidson, W. N. and Worrell, D. L. (1990) 'A comparison and test of the use of accounting and stock market data in relating corporate social responsibility and financial performance', Akron Business and Economic Review, 21: 7-19.

Davis, K. (1973) 'The case for and against business assumption of social responsibilities', Academy of Management Journal, 16 (3): 312-22.

Davis, K. and Blomstrom, R. L. (1975) Business and Society: Environment and Responsibility, McGraw-Hill, New York.

Donaldson, T. and Preston, L. E. (1995) 'The stakeholder theory of the corporation: concepts, evidence, and implications', Academy of Management Review, 20 (1): 6591.

Drumwright, M. E. (1994) 'Socially responsible organizational buying: environmental concern as a noneconomic buying criterion', Journal of Marketing, 58 (3): 1-19. 
Drumwright, M.E. (1996), 'Company advertising with a social dimension: the role of noneconomic criteria', Journal of Marketing, 60 (October): 71-87.

Ferrell, O. C., Fraedrich, J., and Ferrell, L. (2002) Business Ethics: Ethical Decision Making and Cases, Houghton Mifflin Company, Boston.

Fombrun, C. and Shanley, M. (1990), 'What's in a name? Reputation building and corporate strategy', Academy of Management Journal, 33 (2): 233-258.

Fortin, D. (2001), 'La démarche du groupe Suez: le social', in P. d'Humières and A. Chauveau (Eds.), Les pionniers de l'entreprise responsable: 47-53, Editions d'Organisation, Paris.

Fournier, S., Dobscha, S., and Mick, D. G. (1998) 'Preventing the premature death of relationship marketing', Harvard Business Review, 76 (1): 42-51.

Frederick, W. C. (1998) 'Creatures, corporations, communities, chaos, complexity: a naturological view of corporate social role', Business and Society, 37 (4): 358-389.

Gao, S. S., and Zhang, J. J. (2001) 'A comparative study of stakeholder engagement approaches in social auditing', in J. Andriof and M. McIntosh (Eds.), Perspectives on Corporate Citizenship: 239-255, Greenleaf Publishing, UK.

Giraud, B. (2001) 'Danone: la responsabilité sociale à l'épreuve de la mondialisation', in Les pionniers de l'entreprise responsable: 79-87, in P. d'Humières and A. Chauveau, (Eds.), Editions d'Organisation, Paris.

Glazebrook, M. (2001) 'How Australian's top 500 companies are becoming corporate citizens', in J. Andriof and M. McIntosh (Eds.), Perspectives on Corporate Citizenship: 152-165, Greenleaf Publishing, Sheffield, UK.

Gray, B. (1983) 'A preliminary theory of compliance with OSHA regulation', in L. Preston (Ed.), Research in Corporate Social Performance: 121-139, JAI Press, Greenwich, Connecticut. 
Griffin, J. J. and Mahon, J. F. (1997) 'The corporate social performance and corporate financial performance debate', Business and Society, 36 (1): 5-31.

Grönroos, C. (1994) 'Quo vadis, marketing? Toward a relationship marketing paradigm', Journal of Marketing Management, 10 (5): 347-60.

Grönroos, C. (1996) 'Relationship marketing logic', Asia-Australia Marketing Journal, 4 (1): 1-12.

Grönroos, C. (2000) 'Relationship marketing: the Nordic School perspective', in J. N. Sheth and A. Parvatiyar (Eds.), Handbook of Relationship Marketing: 95-117, Sage Publications Inc., Thousand Oaks, California.

The Guardian (1998) 'BP in Columbia: A tale of death, pollution and deforestation', 15 August 1998.

Gummesson, E. (1996) 'Relationship marketing and imaginary organizations: a synthesis', European Journal of Marketing, 30 (2): 31-44.

Gummesson, E. (1999) Total Relationship Marketing: From the 4Ps - Product, Price, Promotion, Place - of Traditional Marketing Management to the 30Rs - the Thirty Relationships - of the New Marketing Paradigm, Butterworth-Heinemann, Oxford.

Handelman, J. M. and Arnold, S. J. (1999) 'The role of marketing actions with a social dimension: appeals to the institutional environment', Journal of Marketing, 63 (3): $33-48$

Håkansson, H. and Snehota, I. J. (2000) 'The IMP perspective: assets and liabilities of business relationships', in J. N. Sheth and A. Parvatiyar (Eds.), Handbook of Relationship Marketing: 69-93, Sage Publications Inc., Thousand Oaks, California.

Jackson, B. B. (1985) Winning and Keeping Industrial Customers, Lexington Books, Lexington, Massachusetts. 
Jones, T. M. (1995) 'Instrumental stakeholder theory: a synthesis of ethics and economic', Academy of Management Review, 20 (2): 404-437.

Klusmann, T. (2000) 'The 100 best corporate citizens', Business Ethics, 16 (2): 13.

Ladurée, J-M. (2001) 'La démarche de l'Oréal', in P. d'Humières and A. Chauveau (Eds.), Les pionniers de l'entreprise responsable: 62-66, Editions d'Organisation, Paris.

Laufer, W. S. (1996) 'Integrity, diligence and the limits of good corporate citizenship', American Business Law Journal, 34 (2): 157-181.

Launay, L-M. (2001) 'La démarche d'IBM France', in P. d'Humières and A. Chauveau (Eds.), Les pionniers de l'entreprise responsable: 54-57, Editions d'Organisation, Paris.

Leonard, M. (1997) 'Count on them in. Corporate America is eager to volunteer help to the needy. The reason is the bottom-line', The Boston Globe, 20 April: F1.

Lindgreen, A. (2000) The Emergence and Rise of Relationship Marketing, Tekst \& Tryk, Copenhagen.

Lindgreen, A., Davis, R., Brodie, R. J., and Buchanan-Oliver, M. (2000) 'Pluralism in contemporary marketing practice', The International Journal of Bank Marketing, 18 (6): 294-308.

Maignan, I. (1997) Antecedents and Benefits of Corporate Citizenship: A Comparison of U.S. and French Businesses. PhD thesis. University of Memphis at Tampa, Tennessee.

Maignan, I. and Ferrell, O. C. (1998) 'Definition and operationalization of corporate citizenship: a cross-cultural approach', in Marketing Exchange Colloquium. American Marketing Association, Vienna. 
Maignan, I. and Ferrell, O. C. (2001) 'Antecedents and benefits of corporate citizenship: an Investigation of French businesses', Journal of Business Research, $51(1): 37-51$.

Maignan, I., Ferrell, O. C., and Hult, T. (1999) 'Corporate citizenship: cultural antecedents and business benefits', Journal of the Academy of Marketing Science, 27 (4): 455-469.

Marsden, C. and Andriof, J. (1998) 'Towards an understanding of corporate citizenship and how to influence it', Citizenship Studies, 2 (2): 329-352.

Martin, R. L. (2002) 'The virtue matrix: calculating the return on corporate responsibility', Harvard Business Review, 80 (3): 68-75.

Mason, E. S. (1960) The Corporation in Modern Society, Harvard University Press, Cambridge, Massachusetts.

McGuire, J. B., Sundgren, A., and Schneeweis, T. (1988) 'Corporate social responsibility and firm financial performance', Academy of Management Journal, 31 (4): 854-872.

McIntosh, M., Leipziger, D., Jones, K., and Coleman, G. (1998) Corporate Citizenship: Successful Strategies for Responsible Companies, Financial Times/Pitman Publishing, the UK.

Menon, A. and Menon, A. (1997) 'Enviropreneurial marketing strategy: the emergence of corporate environmentalism as marketing strategy', Journal of Marketing, 61 (1): 51-67.

Miles, R. H. (1987) Managing the Corporate Social Environment: A Grounded Theory, Prentice-Hall, Englewood Cliffs, New Jersey.

Morgan, R. M. and Hunt, S. D. (1994) 'The commitment-trust theory of relationship marketing', Journal of Marketing, 58 (3): 20-38. 
Murray, K. B. and Vogel, C. M. (1997) 'Using a hierarchy-of-effects approach to gauge the effectiveness of corporate social responsibility to generate goodwill toward the firm: financial versus non financial impacts', Journal of Business Research, 38 (2): 141-159.

Narver, J. C. and Slater, S. F. (1990) 'The effect of market orientation on business profitability', Journal of Marketing, 54 (4): 20-35.

Osterhus, T. L. (1997) 'Pro-social consumer influence strategies: when and how do they work?' Journal of Marketing, 61 (4): 16-29.

Palmer, R. (2001) A Model of Relationship Marketing in Market Maturity. PhD dissertation, Cranfield School of Management, the UK.

Parvatiyar, A. and Sheth, J. N. (2000) 'The domain and conceptual foundations of relationship marketing', in J. N. Sheth and A. Parvatiyar (Eds.), Handbook of Relationship Marketing: 3-38, Sage Publications Inc., Thousand Oaks, California.

Pinkston, T. S. and Carroll, A. B. (1994) 'Corporate citizenship perspectives and foreign direct investment in the US', Journal of Business Ethics, 13 (2): 157-169.

Schultz, D. E., Tannenbaum, S. I., and Lauterborn, R. F. (1992), Integrated Marketing Communications, NTC Business Books, Lincolnwood, Illinois.

Sen, S. and Bhattacharya, C. B. (2001) 'Does doing good always lead to doing better? Consumer reactions to corporate social responsibility', Journal of Marketing Research, 38 (2): 225-243.

Sethi, S. P. (1975) 'Dimensions of corporate social performance: an analytical framework', California Management Review, 17 (3): 58-64.

Sheth, J. N. and Parvatiyar, A. (2000) Handbook of Relationship Marketing. Sage Publications, Thousand Oaks, California. 
Stanwick, S. D. and Stanwick, P. A. (1998) 'Corporate social responsiveness: an empirical examination using the environmental disclosure index', International Journal of Commerce and Management, 8 (3/4): 26-40.

Strand, R. (1983) 'A system paradigm of organisational adaptations to the social environment', Academy of Management Review, 8 (1): 90-96.

Swanson, D. L. (1995) 'Addressing a theoretical problem by reorienting the corporate social performance model', Academy of Management Review, 20 (1): 43-64.

Thomas, A. S. and Simerly, R. L. (1995) 'Internal determinants of corporate social performance: the role of top managers', Academy of Management Journal Best Paper Proceedings: 411-415.

Turban, D. B. and Greening, D. W. (1997) 'Corporate social performance and organizational attractiveness to prospective employees', Academy of Management Journal, 40 (3): 658-672.

Ullmann (1985) 'Data in search of a theory: a critical examination of the relationships among social performance, social disclosure, and economic performance of U.S. Firms', Academy of Management Review, 10 (3): 540-557.

Vance, S. C. (1975) 'Are socially responsible corporations good investment risks?' Management Review, 64 (8): 19-24.

Waddock, S. (2001) 'Integrity and mindfulness: foundations of corporate citizenship', in J. Andriof and M. McIntosh (Eds.), Perspectives on Corporate Citizenship, Greenleaf Publishing, UK: 26-38.

Waddock, S. E. and Graves, S. B. (1997) 'The corporate social performance-financial performance link', Strategic Management Journal, 18 (4): 303-319.

Warhurst, A. (2001) 'Corporate citizenship and corporate social investment: drivers of tri-sector partnerships', Journal of Corporate Citizenship, 1 (Spring): 57-73. 
Wokutch, R. E. and Spencer, B. A. (1987) 'Corporate saints and sinners: the effects of philanthropic and illegal activity on organizational performance', California Management Review, 29 (2): 62-77.

Wood, D. (1991) 'Corporate social performance revisited', Academy of Management Review, 16 (4): 691-718.

Zadek, S. (2001) 'Partnership alchemy: engagement, innovation and governance', in J. Andriof and M. McIntosh (Eds.), Perspectives on Corporate Citizenship: 200-214, Greenleaf Publishing, Sheffield, UK.

Zarkada-Fraser, A. (1999) 'The relationship between market orientation, good corporate citizenship, and customer loyalty', in J. Cadeaux (Ed.), ANZMAC 99 Marketing in the Third Millennium, 28 November/1st December, School of Marketing, University of New South Wales, Sydney, Australia. 
Table 1. Comparison of main components of major schools of thought on relationship marketing versus transaction marketing

\begin{tabular}{|c|c|c|c|c|}
\hline Key Variable & $\begin{array}{l}\text { Transaction } \\
\text { Marketing }\end{array}$ & IMP Group & Nordic School & $\begin{array}{c}\text { Anglo-Australian } \\
\text { Approach }\end{array}$ \\
\hline Basis & Exchange 4Ps & $\begin{array}{l}\text { Relationships between } \\
\text { firms }\end{array}$ & Service & $\begin{array}{l}\text { Service/quality/ } \\
\text { marketing }\end{array}$ \\
\hline Timeframe & Short term & Short and long term & Long term & Long term \\
\hline Market & Single, customer & Multiple, network & $\begin{array}{l}30 \text { markets with four } \\
\text { categories }\end{array}$ & Six markets \\
\hline Organization & $\begin{array}{l}\text { Hierarchical, } \\
\text { functional }\end{array}$ & --- & $\begin{array}{l}\text { Functional and cross } \\
\text { functional }\end{array}$ & $\begin{array}{l}\text { Cross functional } \\
\text { Process based }\end{array}$ \\
\hline Basis of exchange & Price & $\begin{array}{l}\text { Product/service, } \\
\text { information, financial, } \\
\text { and social }\end{array}$ & Less sensitive to price & Perceived value \\
\hline $\begin{array}{l}\text { (Product)/quality } \\
\text { dimension }\end{array}$ & $\begin{array}{l}\text { Product/technical/ } \\
\text { output quality }\end{array}$ & Technological & Interaction quality & $\begin{array}{l}\text { Function of value and } \\
\text { cost of ownership }\end{array}$ \\
\hline Measurement & Revenue market share & Customer profitability & $\begin{array}{l}\text { Quality, value, } \\
\text { customer satisfaction }\end{array}$ & Customer satisfaction \\
\hline Customer information & is ad hoc & $\begin{array}{l}\text { varies by relationship } \\
\text { stage }\end{array}$ & $\begin{array}{l}\text { relates to the } \\
\text { individual }\end{array}$ & $\begin{array}{l}\text { concerns customer } \\
\text { value and retention }\end{array}$ \\
\hline Internal marketing & --- & --- & $\begin{array}{l}\text { Substantial strategic } \\
\text { importance }\end{array}$ & Integral to the concept \\
\hline Service & $\begin{array}{l}\text { Augmentation to core } \\
\text { product }\end{array}$ & $\begin{array}{l}\text { Close seller-buyer } \\
\text { relations }\end{array}$ & Integral to product & $\begin{array}{l}\text { Basis for } \\
\text { differentiation }\end{array}$ \\
\hline
\end{tabular}

Source: Palmer (2001: p. 46). 
Table 2. Types of marketing classified by relational exchange dimensions

\begin{tabular}{|c|c|c|c|c|c|}
\hline & \multirow{2}{*}{$\begin{array}{c}\begin{array}{c}\text { Transactional } \\
\text { Perspective }\end{array} \\
\text { Type: transaction marketing }\end{array}$} & \multicolumn{4}{|c|}{$\begin{array}{l}\text { Relational } \\
\text { Perspective }\end{array}$} \\
\hline & & Type: database marketing & Type: E-marketing & Type: interaction marketing & Type: network marketing \\
\hline Purpose of exchange & Economic transaction & $\begin{array}{l}\text { Information and economic } \\
\text { transaction }\end{array}$ & $\begin{array}{l}\text { Information-generating } \\
\text { dialogue between a seller and } \\
\text { many identified buyers }\end{array}$ & $\begin{array}{l}\text { Interpersonal relationships } \\
\text { between a buyer and seller }\end{array}$ & $\begin{array}{l}\text { Connected relationships } \\
\text { between firms }\end{array}$ \\
\hline Nature of communication & Firm 'to' mass market & $\begin{array}{l}\text { Firm 'to' targeted segment or } \\
\text { individuals }\end{array}$ & $\begin{array}{l}\text { Firm using technology to } \\
\text { communicate 'with' and } \\
\text { 'among' many individuals } \\
\text { (who may form groups) }\end{array}$ & $\begin{array}{l}\text { Individuals 'with' individuals } \\
\text { (across organizations) }\end{array}$ & $\begin{array}{l}\text { Firms 'with' firms (involving } \\
\text { individuals) }\end{array}$ \\
\hline Type of contact & Arms-length, impersonal & Personalized (yet distant) & Interactive (via technology) & $\begin{array}{l}\text { Face-to-face, interpersonal } \\
\text { (close, based on commitment, } \\
\text { trust, and co-operation) }\end{array}$ & $\begin{array}{l}\text { Impersonal - interpersonal } \\
\text { (ranging from distant to } \\
\text { close) }\end{array}$ \\
\hline Duration of exchange & $\begin{array}{l}\text { Discrete (yet perhaps over } \\
\text { time) }\end{array}$ & Discrete and over time & $\begin{array}{l}\text { Continuous (but interactivity } \\
\text { occurs in real time) }\end{array}$ & $\begin{array}{l}\text { Continuous (ongoing and } \\
\text { mutually adaptive, may be } \\
\text { short or long term) }\end{array}$ & $\begin{array}{l}\text { Continuous (stable yet } \\
\text { dynamic, may be short or } \\
\text { long term) }\end{array}$ \\
\hline Formality in exchange & Formal & $\begin{array}{l}\text { Formal (yet personalized via } \\
\text { technology) }\end{array}$ & $\begin{array}{l}\text { Formal (yet customized } \\
\text { and/or personalized via } \\
\text { interactive technology) }\end{array}$ & $\begin{array}{l}\text { Formal and informal (i.e., } \\
\text { both a business and social } \\
\text { level) }\end{array}$ & $\begin{array}{l}\text { Formal and informal (i.e., } \\
\text { both a business and social } \\
\text { level) }\end{array}$ \\
\hline
\end{tabular}

Source: Coviello, Milley, and Marcolin (2001: p. 28) 
Table 3. Types of marketing classified by managerial dimensions

\begin{tabular}{|c|c|c|c|c|c|}
\hline & \multirow{2}{*}{$\begin{array}{c}\begin{array}{c}\text { Transactional } \\
\text { Perspective }\end{array} \\
\text { Type: transaction marketing }\end{array}$} & \multicolumn{4}{|c|}{$\begin{array}{l}\text { Relational } \\
\text { Perspective }\end{array}$} \\
\hline & & Type: database marketing & Type: E-marketing & Type: interaction marketing & Type: network marketing \\
\hline Managerial intent & $\begin{array}{l}\text { Customer attraction (to satisfy } \\
\text { the customer at a profit) }\end{array}$ & $\begin{array}{l}\text { Customer retention (to } \\
\text { satisfy the customer, } \\
\text { increase profit, and attain } \\
\text { other objectives, such as } \\
\text { increased loyalty, decreased } \\
\text { customer risk, etc.) }\end{array}$ & $\begin{array}{l}\text { Creation of IT-enabled } \\
\text { dialogue }\end{array}$ & $\begin{array}{l}\text { Interaction (to establish, } \\
\text { develop, and facilitate a co- } \\
\text { operative relationship for } \\
\text { mutual benefit) }\end{array}$ & $\begin{array}{l}\text { Co-ordination (interaction } \\
\text { between sellers, buyers, and } \\
\text { other parties across multiple } \\
\text { firms for mutual benefit, } \\
\text { resource exchange, market } \\
\text { access, etc.) }\end{array}$ \\
\hline Managerial focus & Product or brand & $\begin{array}{l}\text { Product/brand and customers } \\
\text { (in a targeted market) }\end{array}$ & $\begin{array}{l}\text { Managing IT-enabled } \\
\text { relationships between the firm } \\
\text { and many individuals }\end{array}$ & $\begin{array}{l}\text { Relationships between } \\
\text { individuals }\end{array}$ & $\begin{array}{l}\text { Connected relationships } \\
\text { between firms (in a network) }\end{array}$ \\
\hline Managerial investment & $\begin{array}{l}\text { Internal marketing assets } \\
\text { (focusing on product/service, } \\
\text { price, distribution, promotion } \\
\text { capabilities) }\end{array}$ & $\begin{array}{l}\text { Internal marketing assets } \\
\text { (emphasizing } \\
\text { communication, } \\
\text { information, and database } \\
\text { technology capabilities) }\end{array}$ & $\begin{array}{l}\text { Internal operational assets (IT, } \\
\text { website, logistics); functional } \\
\text { systems integration }\end{array}$ & $\begin{array}{l}\text { External market assets } \\
\text { (focusing on establishing and } \\
\text { developing a relationship } \\
\text { with another individual) }\end{array}$ & $\begin{array}{l}\text { External market assets } \\
\text { (focusing on developing the } \\
\text { firms position in a network of } \\
\text { firms) }\end{array}$ \\
\hline Managerial level & $\begin{array}{l}\text { Functional marketers (e.g., } \\
\text { sales manager, product } \\
\text { manager) }\end{array}$ & $\begin{array}{l}\text { Specialist marketers (e.g., } \\
\text { customer service manager, } \\
\text { loyalty manager) }\end{array}$ & $\begin{array}{l}\text { Marketing specialists (with) } \\
\text { technology specialists; senior } \\
\text { managers }\end{array}$ & $\begin{array}{l}\text { Employees and managers } \\
\text { from across functions and } \\
\text { levels in the firm }\end{array}$ & Senior manager \\
\hline
\end{tabular}

Source: Coviello, Milley, and Marcolin (2001: p. 28) 


\section{Table 4. Some research and managerial considerations about corporate citizenship}

Corporate citizenship is 'the firm's consideration of, and response to, issues beyond the narrow economic, technical, and legal requirements of the firm [...] to accomplish social benefits along with the traditional economic gains which the firm seeks' (Davis 1973: 313).

'Corporate social responsibiliy implies bringing corporate behavior up to a level where it is congruent with the prevailing social norms, values, and expectations' (Sethi 1975).

'Corporate social responsibility is the managerial obligation to take action to protect and to improve both the welfare of society as a whole and the interest of organizations' (Davis and Blomstrom 1975).

'Corporate citizenship is concerned with the relationship between companies and society - both the local community, which surrounds a business and whose members interact with its employees, and the wider and increasingly worldwide community, which touches every business through its products, supply chain, dealer network, and its advertising, among other things' (McIntosh, Leipziger, Jones, and Coleman 1998: xx).

'Good corporate citizenship can be defined as understanding and managing a company's wider influences on society for the benefit of the company and society as a whole' (Marsden and Andriof 1998, quoted in Andriof and Marsden 2000: 2).

In a World Bank program on corporate citizenship, social responsibility has been defined as 'the practice of matching companies with the rest of society [...] corporate citizens are engaging in partnerships for community development all over the world' (Altman 1998: 44).

'Corporate social responsibility is a concept whereby companies integrate social and environmental concerns in their business operations and in their interactions with their stakeholders on a voluntary basis' (European Union, www.europa.eu.int/comm/employment_social/soc-dial/csr/csr_index.htm).

'Corporate social responsibility is operating a business in a manner that consistently meets or exceeds the ethical, legal, commercial, and public expectations that society has of business' (CSR Europe, www.csreurope.org). 


\section{Biographical Sketches}

\section{Adam Lindgreen, PhD}

Adam Lindgreen holds a $\mathrm{PhD}$ in marketing at Cranfield University (England). He is now with Eindhoven University of Technology (the Netherlands) where he is a research fellow with the Eindhoven Centre for Innovation Studies. Dr. Adam Lindgreen has published in Psychology \& Marketing, Journal of Marketing Management, Journal of Customer Behaviour, Journal on Chain and Network Science, Journal of Brand Management, and Journal on Relationship Marketing, amongst others. For his research, Adam Lindgreen has received five awards. He is on the editorial advisory and/or review board of a number of journals, including Journal on Chain and Network Science, Journal of Euromarketing, British Food Journal, Qualitative Market Research, and Marketing Intelligence \& Planning.

\section{Valérie Swaen, MA}

Valérie Swaen is a research fellow with the Belgian National Fund for Scientific Research and Bernheim Fondation and a PhD student with the Catholic University of Louvain (Belgium). She is also a visiting research fellow with the IESEG School of Management (France). Her $\mathrm{PhD}$ research examines consumers' perceptions and reactions to corporate citizenship activities in terms of consumer trust, commitment, and loyalty. She has published papers for international marketing conferences including European Marketing Academy Conference, Association for Consumer Research, Academy of Marketing Science, and Association Française du Marketing. 